\title{
Imports, Productivity Growth, and Supply Chain Learning
}

\author{
Garrick Blalock $^{\dagger}$ \\ Cornell University \\ Department of Applied Economics and Management \\ 346 Warren Hall \\ Ithaca, NY 14853 USA \\ +1 (607) 255-0307 office, +1 (607) 277-0279 residence \\ +1 (607) 255-9984 fax \\ garrick.blalock@cornell.edu
}

\begin{abstract}
Francisco M. Veloso
Carnegie Mellon University

Department of Engineering and Public Policy

5000 Forbes Ave., Pittsburgh, PA 15213 USA

fveloso@cmu.edu

and

Universidade Catolica Portuguesa

Faculdade de Ciencias Economicas e Empresariais
\end{abstract}

1649-023 Lisboa, Portugal

September 25, 2006

${ }^{\dagger}$ Corresponding Author 


\title{
Imports, Productivity Growth, and Supply Chain Learning
}

\begin{abstract}
Summary
We present evidence that importing is a source of international technology transfer. Using a detailed panel of Indonesian manufacturers, our analysis shows that firms in industries supplying increasingly import-intensive sectors have higher productivity growth than other firms. This finding suggests that linkages through vertical supply relationships are the channel through which import-driven technology transfer occurs. To our knowledge, these are the first firm-level results showing that downstream imports play a role in productivity gains. Together with the literature linking FDI and exporting to technology spillovers, the results provide a third component to the argument that trade and openness promote economic growth.
\end{abstract}

Keywords: Technology Transfer, Productivity, Imports, Supply Chain, Southeast Asia, Indonesia

JEL classification: F2, O1, O3 


\section{Acknowledgements}

We thank the participants in seminars at Carnegie Mellon University, the Academy of Management, and the annual meeting of the Portuguese Society for Research in Economics for their valuable comments. We especially acknowledge the suggestions of Peter Thompson, Robert Lowe, James Blalock, and three anonymous referees. Errors remain our own. 


\section{INTRODUCTION}

The international economics literature has had a lasting interest in the relationship between trade and technology transfer (Keller, 2000; Saggi, 2002; Werner, 2002). Early studies using aggregate country-level data suggest trade is an important driver of economic growth. These findings have prompted a stream of research on firm-level mechanisms that support these aggregate findings.

Existing research has mostly focused on two mechanisms: exports by local firms and foreign direct investment (FDI) by multinational firms. The majority of studies associate both mechanisms with increases in productivity, although the direction of the causality is still under scrutiny. But much less effort has been devoted to the export counterpart, imports, which are the focus of this paper. In particular, few studies have used firm-level data to examine imports as a mechanism for technology transfer (Keller \& Yeaple, 2003; Fernandes, 2003; Muendler, 2004; Amiti \& Konings, 2005; MacGarvie, 2006), and the results so far have been mixed.

This paper asks whether imports can improve firm technological capabilities, as measured by productivity gains. Using a rich panel dataset on Indonesian manufacturers from 1988 to 1996, we examine factory productivity growth and its relation to imports in downstream industries. We control for the potential endogeneity between imports and productivity by conditioning on static industry- and firm-level attributes and by considering only import activity largely exogenous to the focal firm. We find strong evidence that firms selling to sectors that rely more on imports have greater productivity growth than other firms. This finding is consistent with the hypothesis that vertical supply 
relationships are an important mechanism through which import-driven technology transfer occurs. Identifying imports as a source of international technology transfer adds a critical third component, along with exports and FDI, to the argument that trade promotes economic growth.

The paper is organized as follows. The next section discusses the theoretical and empirical literature on the relationship between trade, technology, and productivity growth with particular attention to the role of imports and the importance of the supply chain structure. Section 3 provides some background on the liberalization of Indonesia's trade regime and Section 4 discusses the data. Section 5 highlights our econometric identification strategy, Section 6 presents the results, and Section 7 concludes.

\section{TRADE, TECHNOLOGY TRANSFER AND FIRM PRODUCTIVITY}

(a) Trade and technology transfer: what do we know?

Most north-south models of endogenous economic growth emphasize a product life cycle perspective of trade (see, for example, Grossman \& Helpman, 1995). They posit that innovative products are created in the North and, due to lower relative wages, Southern firms can undercut Northern producers' prices if they can obtain the relevant technology. Firms in catch-up economies thus have incentives to acquire advanced technologies created elsewhere and the literature often cites cross-border knowledge flows as a channel for this acquisition (see Keller, 2001 and Saggi, 2002, for recent reviews of these issues). However, empirical evidence of international knowledge flows 
and their impact on technological capabilities in the less developed environment is limited.

The early and perhaps best known literature exploring international knowledge spillovers used country-level data to correlate economic growth with increased openness to trade. Despite many papers addressing this issue, no consensus exists. For example, Sachs \& Warner (1995) find empirical support for the view that open economies grow faster, while Rodriguez \& Rodrik (1999) discuss the problems with existing empirical work and argue against a causal relationship between openness and growth. More targeted research has addressed the potential effect of international knowledge spillovers. Analyzing data for the OECD, Eaton \& Kortum (1996) attribute more than 50 percent of the growth in some countries to innovation in the United States, Germany, and Japan. Also using country-level data, Coe \& Helpman (1995) and Coe, Helpman, \& Hoffmaister (1997) likewise suggest that international technology spillovers are substantial and that trade plays an important role in these spillovers. Connolly (2001) specifically identifies imports in high technology sectors as a major source of productivity and economic growth. In contrast, Keller (1998) performs a similar analysis to Coe \& Helpman (1995) and Coe, Helpman, \& Hoffmaister (1997), but finds no statistical support to relate trade and technology diffusion. Recent studies that use industry-level data (Feenstra, Markusen, \& Zeile, 1992; Keller 1997, 2000) or that separate general trade from capitalgoods trade (Xu \& Wang, 1999) again show imports to increase productivity growth. A limitation of these studies is that, by using country- or industry-level data, they have few observations and often cannot establish causality. In addition, it is difficult to isolate the channels that contribute to technology transfer and results differ with the particular 
definitions of the variables in the analysis.

The limitations of country- and industry-level data motivated efforts to use firmlevel data to evaluate the role of trade in growth and international knowledge spillovers. An early example is Irwin \& Klenow (1994), which studied the semiconductor industry and found technological externalities to be as large internationally as they were in the firm's home economy. In this new firm-level research, two aspects of trade have caught most of researchers’ attention: exports and foreign direct investment (FDI). Several studies have investigated whether entering a foreign market through exporting is a mechanism through which firms learn (for example, Roberts \& Tybout, 1997; Clerides, Lach, \& Tybout, 1998; Bernard \& Jensen, 1999; Aw, Chung, \& Roberts, 2000; Delgado, Fariñas, \& Ruano, 2002; Van Biesebroeck, 2003; Blalock \& Gertler, 2004). Results are mixed and vary with market characteristics and the initial conditions of the firms that decide to export. Likewise, a growing literature on the role of FDI in technology transfer and productivity growth has produced conflicting evidence (see Blomstrom \& Kokko, 1998; Kumar, 1996; Keller, 2001; Moran, 2001; and Keller, 2004, for extensive reviews).

Recent work by Blalock (2002), Javorcik (2004), Kugler (2006), Jabbour \& Mucchielli (2007), and Blalock \& Gertler (2007) examine this contradicting evidence. These papers’ empirics distinguish horizontal spillovers, an externality generated by foreign entry in the same industry, from vertical technology transfer, the often deliberate sharing of technology with clients or suppliers of the foreign entrant. The work notes that most of the conflicting empirical studies have measured horizontal spillovers and argues that multinationals’ efforts to minimize technology leakage may explain the varying findings. On the contrary, this new research argues that vertical technology transfer is 
more likely because foreign entrants have incentives to encourage technology diffusion to suppliers.

But while research looking at firm-level spillover effects of FDI and exports mounts, the role of imports as a mechanism for technology transfer has been much less explored, especially at the level of the firm. A recent stream of papers (many still unpublished) has begun to look at this issue, though with mixed results. Using data from French firms Macgarvie (2006) shows that firms that import cite more foreign patents than non-importers, suggesting that imports may indeed be an important learning mechanism. The paper does not test if such learning impacts firm performance. Amiti \& Konings (2005) do look at the role of imports as a driver of productivity, albeit indirectly. While their work focuses on the impact of tariff reduction on productivity, the analysis shows that importing firms benefit substantially more from liberalization when compared to non-importing ones.

Four recent studies address specifically the potential impact of imports on firm productivity. Analyzing Colombian firms, Fernandes (2003) finds that import penetration of intermediate goods has a large, positive, and significant impact on plant productivity. Results show that a 1 percent increase in import penetration increases plant productivity by 0.6 percent. Kasahara \& Rodriguez (2004) find equally significant results when observing Chilean plants, though with less magnitude; a 1 percent increase in the share of imports increased productivity between 0.14 and 0.20 percent. In contrast, an analysis of US multinationals by Keller \& Yeaple (2003) concludes that imports do not influence plant productivity after controlling for endogeneity. Muendler (2004) is closest to our work. In his study of trade liberalization and the productivity of Brazilian plants, he 
considers two potential effects of imports. The first is the direct effect of imports on importers and, like Keller \& Yeaple (2003), he finds no impact on productivity. The second is the threat of and the effective penetration of imported intermediate goods, both of which cause domestic intermediate goods producers to increase productivity.

(b) The argument: imports, technology transfer and supply chains

Existing models of productivity gains from importing (see Connolly, 2001; Keller, 2001; Rivera-Batiz \& Romer, 1991) emphasize two mechanisms. In the first mechanism, learning occurs through the incorporation of new intermediate products invented abroad in the local production chain. The use of foreign intermediate products conveys the embodied technological capability and R\&D of the foreign producer. For example, an engine producer may decide to import the engine block if the foreign supplier controls the tolerances more tightly than domestic suppliers. Because of the tighter tolerances, the engine assembly process is faster and productivity rises. An alternative example is a shoe producer that switches to imported leather because its better malleability allows the creation of more intricate shapes, enabling the production of shoes with greater value added. (An equivalent reasoning exists when imported capital goods are incorporated in production. Since the focus of this paper is imports of intermediate goods, we do not explore this aspect in detail. See Rodrik, 1999, for a complete discussion.)

As shown in the previous section, direct importing of intermediate goods is the mechanism most explored by existing work and yields conflicting results. In fact, while 
this mechanism for productivity growth is intuitive, it is difficult to assess empirically for two reasons. First, a change in productivity occurs only if the imported intermediate good can be obtained for less than the full value of the new technology embodied in it. Since they are of superior quality, one would expect that the foreign engine block and foreign leather cost more than local substitutes. Productivity thus rises only if this increase in cost is less than the benefit it generates for the buyer. Second, even if learning occurs, econometric measurement is difficult because of endogeneity problems. The decision to import is likely contemporaneous with unobserved (to the econometrician) positive productivity shocks, a problem that existing work has tried to alleviate (e.g., Keller \& Yeaple, 2003, and Muendler, 2004). These difficulties discouraged us from examining the direct effect of imports on the importers and suggested focusing on an alterative mechanism for learning from imports.

The second mechanism for learning from importing is exposure to foreign technology. An original design invented in a particular region is learned elsewhere, for example, by reading a patent, reverse engineering a product, or licensing a technology. Learning the new design raises productivity by increasing the firm’s technological expertise. This mechanism is easy to operationalize and test at the aggregate economy level (see Connolly, 2001 and Rivera-Batiz \& Romer, 1991). But, econometric identification of the phenomenon at the firm level requires careful consideration of how the learning occurs.

Recall the example of the engine assembler that decides to import engine blocks because of the tighter tolerances. As it starts to work with the foreign supplier, it becomes aware of the technologies that are superior to those of the domestic suppliers. Still, to the 
extent that this assembler is in the business of engine assembly, not engine block manufacturing, it has no direct use for this new knowledge. As a result, no productivity enhancement occurs (beyond that described above in the context of the first learning mechanism). But, another group of firms could benefit from the awareness of these new technologies: the domestic engine block manufacturers that could supply the assembler. Local suppliers of equivalent intermediate products have strong incentives to adopt technologies that enable them to compete better with and eventually displace foreign suppliers. In addition, holding price and quality constant, a domestic client will prefer a local supplier to a foreign one because a local transaction poses fewer logistics and exchange rate risks. Clients thus have an incentive to help local suppliers in finding and acquiring technologies that enable them to compete with foreign suppliers. In fact, the management literature (Womack, Jones, \& Roos, 1990; Lamming 1993; Nishiguchi, 1994) has long acknowledged this role that clients play in transferring knowledge to and building the capabilities of suppliers, especially in complex supply chains such as automotive or machinery industries (Dyer and Ouchi, 1993; Cohen, Bessant, Kaplinsky, \& Lamming, 2002; Tendler \& Amorim 1996). The mechanism is similar to the notion of vertical technology transfer from foreign entrants to suppliers explored by Blalock (2002) and Javorcik (2004), with the conduit being imports rather than investment.

One may question why a profit-maximizing domestic supplier would not adopt the most efficient means of production available, even in the absence of international competition from imports. Three reasons may, in part, offer an explanation. First, in a market confined to local competition, knowledge about the latest technologies and business methods may be absent. Second, without outside pressure, the benefits of 
adopting a new technology may not justify the uncertainty and cost of the effort incurred by non-owner managers - a form of x-inefficiency. Third, in a context of only local competition, the additional returns (losses) from (not) investing in a new technology may be very small. But, if a foreign supplier enters and uses superior technology to steal market share from local suppliers, all three of these reasons would be annulled.

These considerations support the base hypothesis that we explore: that learning from imports will occur among local suppliers upstream of import-intensive sectors. We expect, ceteris paribus, that local firms supplying industries and regions with increasing levels of foreign inputs will show greater productivity growth than other local firms.

It is important to qualify this expectation in three ways. First, if the learning mechanism we describe is associated with exposure to new technologies previously unknown in the domestic economy, one should expect to find a declining marginal effect. Early exposure to downstream imports ought to bring the greatest opportunities for learning, as well as competitive pressure to local suppliers. Further import market share gains bring new information at slower rate. After some point, import growth may actually signal the decline of an entire supply sector in the domestic economy. Second, we expect to find the productivity effect to be greater in supply industries with high firm concentration. Firms in these concentrated industries are typically subject to less local competitive pressures and, therefore, exposure to international competition will likely have a greater marginal productivity gain. Third, we need to consider that the cause of measured productivity improvement may be survival rather than learning. As downstream firms begin importing, unproductive suppliers may be unable to compete and may exit the market. We would then observe a rise in average productivity, even 
productivity remains unchanged among firms that survive. We will empirically address these issues below to determine the robustness of our base hypothesis.

\section{INDONESIAN MANUFACTURING AND TRADE POLICY}

Indonesia's manufacturing sector is an attractive setting for research on technology transfer from importing for five reasons. First, with the fourth largest population in the world and thousands of islands stretching over three time zones, the country has abundant labor and natural resources to support a large sample of manufacturing facilities in a wide variety of industries. Second, Indonesian government agencies employ a number of well-trained statisticians who have collected exceptionally rich manufacturing data for a developing country. Third, the country's size and resources support a full supply chain, from raw materials to intermediate and final goods. Fourth, rapid and localized industrialization provides variance in manufacturing activity in both time and geography. Fifth, the country's widespread island archipelago geography and generally poor transportation infrastructure create a number of local markets, each of which can support somewhat independent supply chains. Although regional disaggregation is not necessary for our results, it improves our identification by allowing variation in importing activity between regions but within the same industry.

Changes in the Indonesian trade regime provide a high degree of largely exogenous variation in imports, critical for our study, over the period of our panel. The Indonesian government legislated a set of major reforms of the trade regime in the midand late-1980s, shifting from a policy of import substitution to one of export promotion 
(for a full account of this process see, for example Pangestu, 1997; Hill, 1996, 1999). In 1986, Indonesia substantially reduced import tariffs, reformed customs administration, and introduced a generous duty drawback scheme, thus prompting an overall growth in the import market. Amiti \& Konings (2005) document that these tariff reductions continued into the 1990s and prompted significant increases in imports. According to the World Trade Organization (Economic Research and Statistics Division, Statistics Gateway database), overall manufactured product imports to Indonesia more than doubled from 1988 to 1996 . As a result, the overall share of imported intermediate materials in Indonesian manufacturing has grown from 28 to 35 percent from 1988 to 1996. Among these, chemicals were the largest import class, followed by automotive products. Others industries high on the imports list include electronic components, iron and steel, and textiles.

\section{DATA}

The analysis is based on data from the Republic of Indonesia’s Budan Pusat Statistik (BPS), the Central Bureau of Statistics. ${ }^{1}$ The primary data are an annual census of manufacturing establishments with more than 20 employees conducted by Biro Statistik Industri, the Industrial Statistics Division of BPS. Additional data include price deflators and the input-output table. We describe each dataset below.

The principal dataset is the Survei Tahunan Perusahaan Industri Pengolahan (SI), the Annual Manufacturing Survey. The SI dataset is a complete enumeration of manufacturing establishments with 20 or more employees from 1975 onward. The SI includes questions about industrial classification (89 input-output table codes), ownership 
(public, private, foreign), fixed assets, income, output, exports, materials (and share imported), labor, and other related topics. BPS submits a questionnaire annually to all registered manufacturing establishments, and field agents attempt to visit each nonrespondent to either encourage compliance or confirm that the establishment has ceased operation. ${ }^{2}$ In recent years, BPS has surveyed over 20,000 factories annually.

Government laws guarantee that the collected information will only be used for statistical purposes. However, several BPS officials commented that some establishments intentionally misreport financial information out of concern that tax authorities or competitors may access the data. Because the fixed-effect analysis used here admits only within-factory variation on a logarithmic scale, errors of under- or over-reporting will not bias the results provided that each factory consistently misreports over time. Further, even if the degree of misreporting for a factory varies over time, the results are unbiased provided the misreporting is not correlated with other factory attributes in the right-handside of the regression.

Inter-industry supply chains are calculated using input-output (IO) tables that BPS published in 1990 and 1995. The tables show the value added of goods and services produced by economic sector and how this value is distributed to other economic sectors. The IO tables divide manufacturing activity into 89 sectors and BPS provides concordance tables linking the 1990 and 1995 IO codes to 5-digit ISIC codes used in the SI as described in the data appendix.

The analysis starts in 1988, the first year data on firm capital are available. To avoid measurement error in price and other uncertainties introduced by the 1997-1998 Asian financial crisis, the last year of analysis is 1996. Values for output, materials, 
capital, and energy are deflated to express values in real terms. The deflators are based on Indeks Harga Perdangangan Besar (IHPB), wholesale price indexes (WPI), published by BPS. The data appendix details the construction of the deflators.

\section{IDENTIFICATION STRATEGY AND ESTIMATION}

We have hypothesized that firms selling to import-intensive sectors experience greater productivity growth than other firms. We test this hypothesis by estimating an establishment-level transcendental logarithmic (translog) production function. The translog production function is second-order logarithmic approximation of production that places no functional form restrictions on input substitution or returns to scale. The translog also controls for input levels and scale effects. The core of our paper is to examine whether the residual in the translog production function is correlated with importing in downstream sectors.

We cannot consistently estimate a production function with ordinary least squares if our variable of interest, downstream importing, is correlated with the error term. Such correlation is likely to the extent that downstream importing is endogenous to industryand firm-level unobservables. We adopt four approaches to correct for this endogeneity. First, we control for static firm-level (and by extension, industry- and region-level) unobservables by introducing firm fixed-effects. Our estimation is thus based only on changes in firm productivity associated with changes in downstream imports. Second, we consider only variation in downstream importing that derives from import changes in industries other than that of the focal firm. Third, we control for two time-variant 
variables, foreign ownership and downstream foreign direct investment, which might move contemporaneously with downstream importing activity. Finally, although we believe it to be unlikely, there could be correlation between the error terms associated with particular firm-year observations and importing in other sectors downstream. We thus employ a semi-parametric estimator to condition on idiosyncratic productivity shocks that might simultaneously affect productivity and importing in other sectors. We detail our estimation approach below and elaborate on each of these empirical strategies.

Our goal is to evaluate the productivity impact of downstream imports, which we calculate in two steps. First, we use Equation 1 to estimate own-sector imports, i.e., the degree to which a sector relies on imported materials. The measure varies by industry, time, and region, with $i$ representing a factory, $j$ an industry, $r$ a region, and $t$ the time (year). Purchases $_{i t}$ is the amount of materials purchased by factory $i$ at time $t$ and Foreign_Purchases ${ }_{i t}$ is the corresponding value for purchases made from overseas suppliers. The data includes the 89 different industrial sectors, as defined by the inputoutput Table. The region definitions are the 14 provinces on the most industrialized islands of Sumatra and Java (and neighboring Bali). We exclude the provinces located in Indonesia's outer islands and the former Portuguese colony of East Timor because what little industrial activity that occurs in those areas is largely related to natural resource extraction rather than new goods production. Although not required to identify our critical parameter, the regional approach of assuming local markets improves the statistical power of our estimates while appealing to Indonesia's vast island geography and poor inter-region transportation infrastructure, i.e. firms in the same region are more likely to consume that region's intermediate goods output. 


$$
\begin{gathered}
\text { Own_Sector_Imports }_{j r t}=\frac{\sum_{i \in j r t} \text { Foreign_Purchases }_{i t}}{\sum_{i \in j r t} \text { Purchases }_{i t}} \\
\text { Downstream_Imports }_{j r t}=\sum_{k} \alpha_{j k t} \text { Own_Sector_Imports }_{k r t}
\end{gathered}
$$

The estimates of own-sector imports are then used to estimate our critical variable, the presence of imports in client sectors. Potential for supply chain technology transfer is measured using the Downstream_Imports ${ }_{j r t}$ variable. As shown in equation 2, this variable is calculated by summing the output shares purchased by client manufacturing sectors, $\alpha_{j k t}$, multiplied by the share of own-sector imports in those sectors. For example, suppose that half of the wheat flour sector output is purchased by the bakery industry and the other half is purchased by the pasta industry. Further, suppose that the bakery industry has no foreign purchases but that the pasta sector buys half of its inputs from abroad. The calculation of downstream import penetration for the flour sector would yield $0.25=0.5(0.0)+0.5(0.5)$. More formally, $\alpha_{j k t}$ is the proportion of output of sector $j$ consumed by sector $k$ at time $t$ from the national input-output (IO) tables. Values of $\alpha_{j k t}$ before and including 1990 follow from the 1990 IO table, values of $\alpha_{j k t}$ from 1991 through 1994 are linear interpolations of the 1990 and 1995 IO tables, and values of $\alpha_{j k t}$ for 1996 are from the 1995 IO table. Recall that $\alpha_{j k t}$ does not have a region $r$ subscript because the IO table is generated for the national economy.

Because we do not know which firms are selling to importers, we measure downstream imports as the share of the total output of an industry and region that is sold to downstream importing sectors, weighted by the import-intensity of those sectors. One might prefer to use the actual output sold to importers by each supplier. This would, in 
principle, be the correct measure if the firms selling to importers are the only ones that benefit from the technology transfer. However, importers have incentives to make the technology available to as many suppliers as possible to prevent holdup. If the technology becomes widely available so that all firms in a given industry of a particular region might benefit, then the correct measure would be the share of all output from the industryregion sold to importers, making our measure the one that most accurately reflects the true impact of downstream imports. The truth probably lies somewhere in between, i.e., that the technology is distributed beyond those firms that sell to importers, but not to all firms. Thus, our measure is best interpreted as the effect of an increase in the availability of technology through downstream imports on the average productivity of sellers in a particular industry in a particular region. The direct impact that the decision of a client firm to import materials has on the productivity of its suppliers, which we cannot observe, is probably larger than what we assess with our measure.

We obtain establishment-level productivity by estimating a translog production function: ${ }^{3}$

$$
\begin{aligned}
& \ln Y_{i t}=\beta_{0} \text { Downstream_Importsjrt }+\beta_{1} \ln K_{i t}+\beta_{2} \ln L_{i t}+\beta_{3} \ln M_{i t}+\beta_{4} \ln E_{i t}+ \\
& \beta_{5} \ln ^{2} K_{i t}+\beta_{6} \ln ^{2} L_{i t}+\beta_{7} \ln ^{2} M_{i t}+\beta_{8} \ln ^{2} E_{i t}+ \\
& \beta_{9} \ln K_{i t} \ln L_{i t}+\beta_{10} \ln K_{i t} \ln M_{i t}+\beta_{11} \ln K_{i t} \ln E_{i t}+ \\
& \beta_{12} \ln L_{i t} \ln M_{i t}+\beta_{13} \ln L_{i t} \ln E_{i t}+\beta_{14} \ln M_{i t} \ln E_{i t}+\alpha_{i}+\gamma_{t}+\varepsilon_{i t}
\end{aligned}
$$

where $Y_{i t}, K_{i t}, L_{i t}, M_{i t}$, and $E_{i t}$ are the amounts of production output, capital, labor, materials, and energy for establishment $i$ at time $t, \alpha_{i}$ is a fixed effect for factory $i, \gamma_{t}$ is a indicator variable for year $t$, and $\varepsilon_{i t}$ is an error term. ${ }^{4}$ A positive coefficient on 
Downstream_Imports jrt $_{\text {indicates that downstream imports are associated with higher }}$ productivity in the supply sector. Output, capital, and downstream imports are nominal rupiah values deflated to 1983 rupiah. Labor is the total number of production and nonproduction workers and energy is the sum of deflated electrical and fuel expenditures. Finally, we note that the error term, $\varepsilon_{i t}$, is assumed to be uncorrelated with downstream imports. Our results would be biased if, in fact, upstream firm productivity and downstream imports were simultaneously determined by unobserved idiosyncratic shocks (see Olley \& Pakes, 1996, and Levinsohn \& Petrin, 2003, for a full discussion). We know of no particular economic justification for simultaneity concerns in our data. Further, to the degree that simultaneity exists, we believe it would place a downward bias on the effect of downstream imports because improvements in domestic supplier productivity would likely lead to less importing in downstream sectors. Nonetheless, we have performed our analysis with the corrections proposed by Levinsohn and Petrin (using investment as a proxy for idiosyncratic shocks. The results (not reported here but available from the authors) are virtually unchanged. ${ }^{5}$

To the extent that heterogeneity across firms and industries is static, our fixedeffect estimation should be consistent. However, industries could be changing over time and we employ three measures to address changes that might be contemporaneous with importing activity. First, because foreign-owned firms are more likely to import than wholly Indonesian-owned firms, it would be easy to confound changes in importing behavior with changes in foreign ownership. To avoid this potential effect, the sample used to calculate own imports is limited to wholly Indonesian-owned firms over the entire panel period. ${ }^{6}$ Second, a related concern is that downstream imports are a proxy for 
downstream foreign direct investment (FDI), a factor known to influence upstream firm productivity (Blomstrom \& Kokko, 1998; Blalock, 2002; Javorcik, 2004). ${ }^{7}$ If downstream FDI is highly correlated with downstream imports, it will be crucial to control for FDI to avoid falsely attributing the effect of one to the other. Third, because some sectors supply themselves, downstream imports may be correlated with the direct own-sector imports described above. We control for this possibility by also including the own-sector import variable. Again, because of the potential endogeneity problems with own-sector imports, we do not assign causality to this variable. Rather, we use it simply as a control.

\section{[Insert Table 1 here]}

As noted in Section 2.(b), we argue that exposure to downstream imports should be most relevant when imports first enter a firm's downstream market. As the share of imports continues to grow, the marginal impact on productivity may start to decline. To test this idea, we estimated the base model adding the square of downstream imports. Our expectation is to find a negative coefficient on the squared term. A second aspect discussed in section 2.(b) was that downstream imports would have a greater effect on less competitive domestic industries. To test this idea, we estimated the regression adding a variable for the interaction of the industry Herfindahl concentration and downstream imports. ${ }^{8}$ If downstream imports have a more pronounced productivity effect on less competitive (more concentrated) markets, then the coefficient on the interaction term should be positive.

Table 1 shows descriptive statistics for downstream imports, downstream FDI, 
and own-sector imports. Downstream imports represent a small proportion of the downstream supply chain. On average, less than 7 percent of the inputs consumed by downstream firms were imported goods. A similarly low value is found for downstream FDI, while the figure is somewhat higher for own-sector imports. The low average value for the downstream imports variable is important evidence that firms were experiencing a mild exposure to the entry of foreign players in downstream markets, rather than large movements towards foreign purchases. Yet, the wide range and large standard deviation of downstream imports provide rich variation that helps our econometric identification.

There is also significant regional variation in downstream imports, both crosssectionally and over time, which we exploit by measuring downstream imports by industry-region-year. For example, consider the textile sector. In Jakarta, located in western Java and one of the more industrialized areas of the country, the share of downstream imports for textiles increased from 0.24 in 1988 to 0.37 in 1996. In Surabaya, another industrialized region in eastern Java, downstream imports for this industry were 0.03 in 1988 and 0.17 in 1996. In contrast, Bali, a less industrialized island off the coast of eastern Java, had downstream imports for textiles of zero in 1988 and only 0.01 in 1996.

Table 2 shows the correlations between the variables of interest. Downstream imports, own-sector imports, and downstream FDI are positively correlated. This finding necessitates our estimation strategy of including all three measures to isolate the only the independent variation in downstream imports. 
[Insert Table 2 here]

Once the main effect of downstream imports is established, we explore two ways in which firm characteristics mediate its impact. First, an immediate corollary of supply chain learning is that firms in intermediate goods sectors ought to learn more through this mechanism than firms in final goods sectors. With a few exceptions, final goods companies have little access to clients that could act as an international link and one would thus expect fewer learning opportunities. We define intermediate goods sectors to be the 37 sectors that sold 50 percent or more of their output to other manufacturing sectors in either the 1990 or 1995 IO table (results are robust to alternative definitions) and test the model for this sample. Second, firm learning may vary with size. Larger firms may have greater resources to access and leverage foreign technology and thus learn more. To test this idea, we define larger firms as those with more than 50 employees and repeat the analysis for this sample. ${ }^{9}$

Another issue noted in Section 2.(b) is that measured productivity improvement can result from survival of only the most productive firms. To separate such survival bias from supply chain learning, we take two complementary approaches. First we control for survival in the baseline model. We follow Maddala (1983) and run a first stage regression to estimate the likelihood of particular firm remaining in the panel the following year. ${ }^{10}$ We then include the predicted survival probabilities from the logistic regression as an additional regressor in the model to correcting for the potential selectivity bias. Second, we restrict the sample to a balanced panel of firms that survive the entire period of 1988 to 1996. If the coefficient on downstream imports in these alternative estimations is close 
to that obtained without the corrections, then we are better able to dismiss survival as an alternative phenomenon to supply chain learning. Because the balanced panel greatly reduces our sample size, we will retain statistical power in our alternative estimations by considering only intermediate goods sectors for which we expect the effect of downstream imports to be most applicable.

A final concern in our estimation strategy is the aggregation level used in the standard error calculation. Although the unit of analysis in our estimation is an individual factory, our key variable of interest, downstream imports, varies at the industry-regionyear level. Moulton (1990) shows that standard errors can be biased downwards if there is correlation in the disturbance terms of individuals units that share a common aggregate variable value. The intuition of the concern is that the presence of many factory observations within each cell of actual downstream imports variation could exaggerate the precision of our standard error estimates. To be sure that our results are robust to any disturbance term correlation, we also estimate Equation 3 with clustering at the industryregion-year level. As described in Hoxby (2005), clustering at this level is a very conservative correction that likely overestimates the magnitude of standard errors. We thus focus on the sample of firms mostly likely to be affected by downstream imports: establishments in intermediate goods industries with at least 50 workers.

\section{RESULTS}

\section{(a) Main Specifications}

The results provide strong evidence that Indonesian supplier productivity benefits 
from downstream imports. Table 3 presents the results of estimating Equation 3. Column (1) displays results with only the effect of downstream imports, which is significant at a 99 percent confidence interval. Because the production function is of log-linear form, the coefficients represent elasticities. The 0.117 coefficient on downstream imports suggests that factory output increases approximately 0.12 percent as the proportion of downstream materials imported rises by 1 percent. Given that the level of downstream imports increased by about 10 percent from 1988 to 1996 in many industries, the realized gain is about a 1 percent increase in output in many sectors. When weighted by firm output, the overall level of downstream imports increased by 5 percent, suggesting about a 0.6 percent (0.12 times 5) increase in productivity from 1988 to 1996 . Since the total increase in productivity in the relevant period is 19 percent, the effect of downstream imports represents roughly 3.15 percent of the total gains in productivity.

\section{[Insert Table 3 here]}

Columns (2) to (4) represent the sets of controls discussed in Section 5. The effect of downstream imports is robust to the introduction of any or all of the relevant control variables. Consistent with Blalock (2002) and Javorcik (2004), downstream FDI, included in columns (2) and (4), is positive and significant. Moreover, the inclusion of downstream FDI in the model lowers the magnitude of downstream imports to roughly half of the value reported in column (1), although the effect remains significant. Columns (3) and (4) confirm the hypothesis that own-sector imports do not affect the main results and are likely to be non-significant. ${ }^{11}$ 
Column (5) tests for the relevance of competition as a critical mechanism for inducing productivity enhancement. The interaction effect between own-sector concentration and downstream imports is positive and significant. ${ }^{12}$ Moreover, the explanatory power of the regression improves significantly. These results support our assertion of the importance of competition. At the same time, we note that the main coefficient on downstream imports is still significant. This suggests that, even with perfect competition (as the Herfindahl index tends to zero), productivity improvement still occurs. We interpret this to mean that supply chain learning from downstream imports occurs above and beyond any competition-based effect of import penetration. Column (6) in this table includes the square of downstream imports. As expected, the coefficient on this term is negative and significant and suggests a declining marginal impact.

Column (7) reports a fully specified model with all variables used in specifications (1) to (6). The coefficients for the variables are in agreement with the prior results, both in terms of overall magnitude as well as levels of significance. The largest difference is the increased role of concentration as a mediating factor on the impact of downstream imports. These results are robust to the elimination of regional variation in our downstream imports variable (not reported but available on request). The standard errors of the critical variables increase, but remain significant.

We note that the coefficients on the regressors for the translog function are stable across all models. To confirm the reasonableness of their magnitudes, we estimated the input elasticities for the translog inputs at their mean levels. The elasticities for labor, capital, materials, and energy were $0.20,0.05,0.65$, and 0.08 respectively. These values 
are in line with typical manufacturing production function elasticities and are similar to the magnitudes found on the same data in Blalock and Gertler (2004).

\section{(b) Robustness Tests: Firm Heterogeneity, Survival and Aggregation}

To explore the hypothesis discussed in Section 5 regarding firm size and position in the supply chain, Table 4 presents the results for large and intermediate goods firms. As predicted, larger firms are benefit more from downstream imports (column 2, 0.110 versus an effect of 0.064 for all firms). Likewise, the results are much stronger for intermediate goods than for final goods sectors (columns 3 and 4, 0.090 for intermediate goods versus 0.037 for final goods firms). All results are robust to the introduction of downstream FDI.

[Insert Table 4 here]

The remaining robustness tests are presented in Table 5. The table omits the translog production function regressors for clearer presentation (they are in line with those reported in previous specifications). The first model includes the predicted probability of survival from the first-stage logit as an additional regressor. The coefficient (column 1) on survival probability is not significant and that the coefficient on downstream imports barely deviates from what had been obtained in the regression without this new control (column 3 of Table 4, 0.101 versus 0.090 without the control). We also obtain similar results of 0.088 (column 2) when we restrict the sample to a balanced panel of firms that survived for the entire panel period. The similarity of these 
results to those without selection corrections suggest that firm entry and exit are not a likely alternative explanations for our results. Finally, column 3 of Table 5 reports regression results with the errors clustered at the industry-region-year level. Even with this conservative test, the effect of downstream imports is still significant.

[Insert Table 5 here]

\section{(c) Sector Analysis}

The analysis so far pools factories in all industries. The advantage of a pooled sample is that it provides high variation in downstream imports. Recall that downstream imports are calculated by industry, as defined in the input-output table, region, and year. Because we use fixed-effect estimation, only the variation about a factory's mean, or within-factory variation, is admitted. We thus examine how within-factory variation differs between industries and regions. If the estimation sample were limited to firms in just one industry, the only remaining between-plant variation in downstream imports would be by region. That is, one would take factories in regions with changes in downstream imports over time as the treatment group, and those in other regions with no changes in downstream imports as the control group. We use Indonesia's provinces as regional indicators and many industries are concentrated in only a few provinces. We thus face that problem that the limited variation between a few provinces is insufficient for a statistically powerful test. Further, if there is little change in downstream imports in a given industry, there may be insufficient within-plant variation. Our base analysis overcomes this problem by pooling all industries together, taking some industries as 
treatment groups and other industries as control groups.

A pooled sample, however, has two limitations. First, because the effect of downstream imports is constrained to be uniform across industries, one cannot identify which industries benefit the most from downstream imports. Second, a pooled sample constrains the return to inputs to be constant across industries. It may be unreasonable to require that the marginal product of capital or labor be uniform across industries as varied as fish processing and electronics assembly. Such a constraint could bias our results, although it is not obvious in what direction. To balance the need for variation in our critical variable and the desire to better understand the sensitivity of individual sectors to the effect of downstream imports, we selected five industry groups for which to test our model: food and beverage, textiles, chemicals, metals, and machinery (corresponding to the 31, 32, 35, 37, and 38 2-digit ISIC codes respectively). We chose these 2-digit ISIC codes because they contain at least one IO-code with 5 percent growth in downstream imports. 2-digit ISIC codes typically span several IO codes with varying degrees of downstream imports. We thus retain some between-firm inter-industry variation, but the industries are closely related and the constant returns to inputs constraint is less problematic. Our selection rule that at least one IO-code has 5 percent greater growth in downstream imports ensures that we also retain some within-firm variation. With this criterion, we leave out wood processing (33), paper (34), mineral products (36), as well as "other industries" (39). Because wood processing and paper are sectors largely associated to local resource extraction and processing, it is not surprising that there is little downstream importing growth. For each industry group, we restrict our sample to firms with more than 50 employees. The sample of larger firms, which we've shown are 
more responsive to downstream imports, helps us retain statistical power with limited variation.

[Insert Table 6 here]

Table 6 shows that three industry groups have positive and significant results: food, machinery and textiles. The coefficient for chemicals is negative, but not significant, while for metals it is positive, but also not significant. Because the observation count for metals is very small (95 firms), it’s unlikely we would have sufficient statistical power to identify an effect. Textiles and machinery are industrial groups in which one would reasonably expect downstream imports to play a role in improving productivity. For example, machinery includes areas such as electronics assembly and automobile assembly, activities with complex and specialized multi-tier supply chains through which technology transfer is common. Similar multi-tier supply chains exist for textile and garment production, albeit to a lesser extent (Gereffi, 1999).

\section{SUMMARY AND IMPLICATIONS}

This study presents evidence that importing is a source of international technology transfer. Using detailed firm-level data from Indonesia, we show that firms selling to sectors with increasing import intensity have higher productivity growth than other firms. These results are consistent under a number of econometric approaches that address potential endogeneity between importing activity and firm productivity as well 
as confounding effects such as FDI, concentration, and survival.

We also find that early exposure to downstream imports brings with it the greatest opportunities for learning, while an increasingly larger presence of imports induces productivity improvements at a declining marginal rate. In addition, results show that productivity improvement is greater in contexts where suppliers are more concentrated, suggesting that competition aids in inducing improvements. The analysis also suggests that exit due to pressure from downstream imports plays little or no role in productivity improvements. Rather, the productivity gains we observe result from improvements in existing firms. Finally, the results imply that large firms and firms in intermediate goods sectors are better able to learn from imports.

Overall, the findings of this research imply that linkages though vertical supply relationships are a relevant mechanism through which import-driven knowledge transfer occurs. To our knowledge, these are the first firm-level results showing that downstream imports play a role in the creation of technological capabilities, as measured by productivity. This is an important contribution to the identification of international knowledge spillovers, a critical component in the argument that trade promotes economic growth. 


\section{ENDNOTES}

1. We identify names in Bahasa Indonesia, the language of most government publications, with italics. Subsequently, we use the English equivalent or the acronym.

2. Some firms may have more than one factory; we refer to each observation as an establishment, plant, or factory. BPS also submits a different questionnaire to the head office of every firm with more than one factory. Although these data were not available for this study, early analysis by BPS suggests that less than 5 percent of factories belong to multi-factory firms. We therefore generalize the results to firms.

3. A joint F-test on the quadratic terms in the translog production function reject the hypothesis that the terms are jointly equal to zero. Hence, we reject a simpler CobbDouglas production function in favor of the more flexible translog functional form. The translog also permits us to allow a non-unitary elasticity of substitution between inputs and thereby better condition on economies of scale.

4. A Hausmann test rejects the use of random effect estimation.

5. We ran Olley-Pakes and Levinsohn-Petrin specifications for our models and obtained very similar results to the fixed effect estimations. In addition, using these alternative approaches would create some significant limitations. First, because the Olley-Pakes estimation is only identified for firms with positive investment, it would force us to throw out a third of our data. Second, there was non-convergence for some models in the numerical optimization in the second stage of the Levinsohn- 
Petrin estimator, which would require us to exclude energy as a separable input. As a result, and because the estimates of our parameters change very little with the adjustment for possible simultaneity, we use the fixed effects estimator. For a detailed analysis on the use of these alternative estimators on the same data see Blalock and Gertler (2004).

6. The results presented subsequently are unchanged if the complete sample of firms is used to estimate imports.

7. Downstream FDI is calculated in two steps much like downstream imports. First, the share of foreign output in a given industry, sector, and time is calculated through the ratio of foreign-owned firms' output to total sector output. Second, for each sector, time, and region, downstream FDI is estimated by summing the output shares purchased by client manufacturing sectors $k$ multiplied by the share of sector foreign output in those sectors.

8. The industry definition here is the IO table industry code. Alternative industry definitions based on 4-digit ISIC codes yield similar results.

9. The results are not sensitive to the definition of size. For example, defining large firms as those with more than 200 employees yields nearly identical results.

10. Predictors of survival in each year in logistic regression include log of employees, log of capital, and 4-digit ISIC dummies.

11. If the endogeneity of a firm's import decision is significant, the coefficient and standard errors may be biased.

12. Concentration may be simultaneously determined by both productivity and downstream imports. To remove this possible endogeneity, we estimated an alternative 
specification in which the concentration index is fixed at the level in 1988, at the start of our panel. Our results are very similar, but significant only at the 90 percent confidence level. It is also possible that more concentrated industries show evidence of greater productivity because of price mark-ups rather than efficiency arguments. In this situation, as downstream imports increase, we should observe a decline in price markups because of import competition. This would be observed as a decline in productivity. Yet, a decline is the opposite of what we have hypothesized, making it harder to identify any potential increase in productivity due to our efficiency argument. The fact that we do observe a significant result and according to our predictions suggests that the productivity improvement induced by downstream international competition is much more important that any loss in price mark-ups.

\section{REFERENCES}

Amiti, M. \& Konings, J. (2005): “Trade Liberalization, Intermediate Inputs, and Productivity: Evidence from Indonesia,” IMF Working Paper WP/05/146.

Aw, B. Y., Chung, S. \&. Roberts, M. J. (2000): "Productivity and Turnover in the Export Market: Micro-level Evidence from the Republic of Korea and Taiwan (China),' The World Bank Economic Review, 14(1), 65-90.

Bernard, A. B., \& Jensen, J. B. (1999): “'Exceptional Exporter Performance: Cause, Effect, or Both?,'’ Journal of International Economics, 47(1), 1-25.

Blalock, G. (2002): “'Technology Adoption from Foreign Direct Investment and 
Exporting: Evidence from Indonesian Manufacturing,'’ Ph.D. thesis, University of California, Berkeley, Haas School of Business.

Blalock, G., \& Gertler, P.J. (2004): “'Learning from Exporting Revisited in a Less Developed Setting,' Journal of Development Economics, 2(75), 397-416.

Blalock, G., \& Gertler, P.J. (2007): "Welfare Gains from Foreign Direct Investment through Technology Transfer to Local Suppliers," Journal of International Economics (forthcoming).

Blomstrom, M., \& Kokko, A. (1998): “'Multinational Corporations and Spillovers,” Journal of Economic Surveys, 12(3), 247-277.

Clerides, S. K., Lach, S. \& Tybout, J. R. (1998): “'Is Learning by Exporting Important? Micro-Dynamic Evidence from Colombia, Mexico, and Morocco,’' Quarterly Journal of Economics, 113(3), 903-947.

Coe, D. T. \& Helpman, E. (1995): “'International R\&D spillovers,’’ European Economic Review, 39(5), 829-859.

Coe, D. T., Helpman, E. \& Hoffmaister, A. W. (1997): “North-south R\&D Spillovers,” The Economic Journal, 107(440), 134-149.

Cohen, W., Bessant, J., Kaplinsky, R. \& Lamming , R. (2002): “'Putting supply chain learning into practice,’' International Journal of Operations and Production Management, 23(2), 167-184.

Connolly, M. P. (2001): “The Dual Nature of Trade: Measuring its Impact on Imitation and Growth,’’ Discussion Paper 31, Duke University, Economics Department, Durham, NC. 
Delgado, M. A., Fariñas, J. C. \& Ruano, S. (2002): “Firm Productivity and Export Markets: A Non-parametric Approach,' Journal of International Economics, 57(2), 397422.

Dyer, J. H., \& Ouchi, W. G. (1993): “Japanese Style Business Partnerships: Giving Companies a Competitive Edge,’' Sloan Management Review, 35(1), 5163.

Eaton, J., \& Kortum, S. (1996): “'Trade in Ideas: Patenting and Productivity in the OECD,’' Journal of International Economics, 40(3), 251-278.

Feenstra, R. C., Markusen, J. R. and Zeile , W.(1992): “Accounting for Growth with New Inputs: Theory and Evidence,” American Economic Review, Vol. 82(2), pp. 415-21.

Fernandes, A. M. (2003): Trade policy, trade volumes, and plant-level productivity in Colombian manufacturing industries. World Bank Policy Research Working Paper Series, No. 3064.

Gereffi, G. (1999): “International Trade and Industrial Upgrading in the Apparel Commodity Chain”. Journal of International Economics 48(1): 37-70

Grossman, G., \& Helpman, E. (1995): “Technology and Trade,” in Handbook of International Economics, ed. by G. Grossman, and K. Rogoff, vol. 3. Elsevier Science.

Hill, H. (1996): The Indonesian Economy since 1966: Southeast Asia's Emerging Giant. Cambridge: Cambridge University Press.

Hill, H. (1999): The Indonesian Economy in Crisis: Causes, Consequences and Lessons. New York: St. Martin's Press. 
Hoxby, C. M. (2005): "Competition Among Public Schools: A Reply to Rothstein (2004)," Working Paper 11216, National Bureau of Economic Research, Cambridge, MA, March.

Irwin, D. A., \& Klenow, P. J. (1994): “'Learning-by-Doing Spillovers in the Semiconductor Industry,’’ The Journal of Political Economy, 102(6), 1200.

Jabbour, L. \& Mucchielli, J.L. (2007): “Technology Transfer through Vertical Linkages: The Case of the Spanish Manufacturing Industry,” Journal of Applied Economics (forthcoming).

Javorcik, B. S.(2004): “'Does Foreign Direct Investment Increase the Productivity of Domestic Firms? In Search of Spillovers through Backward Linkages,’' American Economic Review, 94(3), 605-627.

Kasahara, H. \& Rodrigue, J. (2004), “Does the Use of Imported Intermediates Increase Productivity?” Kingston, Ontario: Queen’s University Working Paper.

Keller, W. (1997): “'Technology Flows between Industries: Identification and Productivity Effects,’’ Economic Systems Research, 9(2), 213-220.

Keller, W. (1998): “'Are International R\&D Spillovers Trade-related? Analyzing Spillovers among Randomly Matched Trade Partners,'’ European Economic Review, 42(8), 1469-1481.

Keller, W. (2000): “'Do Trade Patterns and Technology Flows Affect Productivity Growth?,’' World Bank Economic Review, 14(1), 17-47.

Keller, W. (2001): “'International Technology Diffusion,’’ Working Paper 8573, National 
Bureau of Economic Research, Cambridge, MA., October.

Keller, W. (2004): “'International Technology Diffusion,’’ Journal of Economic Literature, 42(3), 752-782.

Keller, W. \& Yeaple, S. R. (2003): “'Multinational Enterprises, International Trade, and Productivity Growth: Firm Level Evidence from the United States,’’ Discussion paper, University of Texas, Austin, Dept. of Economics.

Kugler, M. (2006) “Spillovers from foreign direct investment: within or between industries? Journal of Development Economics, 80(2), 444-477.

Kumar, N. (1996): “'Foreign Direct Investments and Technology Transfers in Development: A Perspective on Recent Literature,’' Discussion paper, The United Nations University, Institute for New Technologies.

Lamming, R. (1993): Beyond Partnership: Strategies for Innovation and Lean Supply. Prentice-Hall, Englewood Cliffs, NJ.

Levinsohn, J. \& Petrin, A. (2003): “Estimating Production Functions Using Inputs to Control for Unobservables,'” Review of Economic Studies, 70(2), 317-341.

MacGarvie, M. (2006): “'Do Firms Learn from International Trade?’’ Review of Economics and Statistics, 88(1), 46-60.

Maddala, G. S. (1983). Limited-Dependent and Qualitative Variables in Econometrics. Econometric Society Monographs in Quantitative Economics. Cambridge University Press.

Moran, T. H. (2001): Parental Supervision: The New Paradigm for Foreign Direct 
Investment and Development. Institute for International Economics, Washington, DC.

Moulton, B. R. (1990): "An Illustration of a Pitfall in Estimating the Effects of Aggregate Variables on Micro Units," The Review of Economics and Statistics, 72(2), 334-338.

Muendler, M. A., 2004, “Trade, Technology, and Productivity: A Study of Brazilian Manufacturers 1986-1998," CESifo Working Paper No. 1148 (Munich: Ifo Institute for Economic Research).

Nishiguchi, T. (1994): Strategic Industrial Sourcing: The Japanese Advantage. Oxford University Press, New York.

Olley, G. S., \& Pakes, A. (1996): “The Dynamics of Productivity in the Telecommunications Equipment Industry,'” Econometrica, 64(6), 1263-1297.

Rivera-Batiz, L. A., \& Romer, P. A. (1991): “'Economic Integration and Endogenous Growth,'” Quarterly Journal of Economics, 106(2), 531-556.

Pangestu, M (1997): “Indonesia: Trade and Foreign Investment Linkages” in W. Dobson and C. Yue (eds.) Multinationals and East Asian Integration. Ottawa: IDRC Publishers.

Roberts, M. J., \& Tybout, J. R. (1997): “The Decision to Export in Colombia: An Empirical Model of Entry with Sunk Costs,'” American Economic Review, 87(4), 545564.

Rodriguez, F., \& Rodrik, D. (1999): “'Trade Policy and Economic Growth: A Skeptic’s Guide to the Cross-country Evidence,’ Working Paper 7081, National Bureau of 
Economic Research, Cambridge, MA, April.

Rodrik, D. (1999) The New Global Economy and Developing Countries: Making Openness Work. Washington, DC: Overseas Development Council; Baltimore, MD. Johns Hopkins University Press.

Sachs, J. \& Warner, A. (1995): “Economic Reform and the Process of Global Integration,’' Brookings Papers on Economic Activity, 1, 1-118.

Saggi, K. (2002): “'Trade, Foreign Direct Investment, and International Technology Transfer: A Survey,” World Bank Research Observer.

Tendler, J. \& Amorim, M. A. (1996): “'Small Firms and Their Helpers: Lessons on Demand,’' World Development, 24(3), 407-426.

Van Biesebroeck, J. (2003): “Exporting Raises Productivity in Sub-Saharan African Manufacturing,' Working Paper 10020, National Bureau of Economic Research, Cambridge, MA, October.

Werner, S. (2002): “'Recent Development in International Management Research: A Review of 20 top Management Journals,'” Journal of Management, 28(3), 277-305.

Womack, J. P., Jones, D. T \& Roos, D. (1990): The Machine that Changed the World. Rawson Associates, New York.

Xu, B., \& Wang, J. (1999): “Capital Goods, Trade and R\&D Spillovers in the OECD,” Canadian Journal of Economics, 32(5), 1258-1274. 


\section{Tables}

Table 1: Descriptive Statistics.

\begin{tabular}{cccccc}
\hline \hline Variable & Obs. & Mean & Std. Dev. & Min & Max \\
\hline Downstream Imports & 6169 & 0.069 & 0.110 & 0 & 0.903 \\
& & & & & \\
Downstream FDI & 6169 & 0.050 & 0.106 & 0 & 0.987 \\
& & & & & \\
Own-sector Imports & 6126 & 0.172 & 0.277 & 0 & 1.000 \\
\hline \hline
\end{tabular}

The unit of observation is the industry-province-year cell.

Table 2: Correlation of key variables.

\begin{tabular}{lccc}
\hline \hline & Downstream Imports & Downstream FDI & Own-sector Imports \\
Downstream Imports & 1.0000 & & \\
Downstream FDI & 0.6107 & 1.0000 & 1.0000 \\
Own-sector Imports & 0.4342 & 0.2519 & \\
\hline \hline
\end{tabular}


Table 3: Effect of imports on plant productivity.

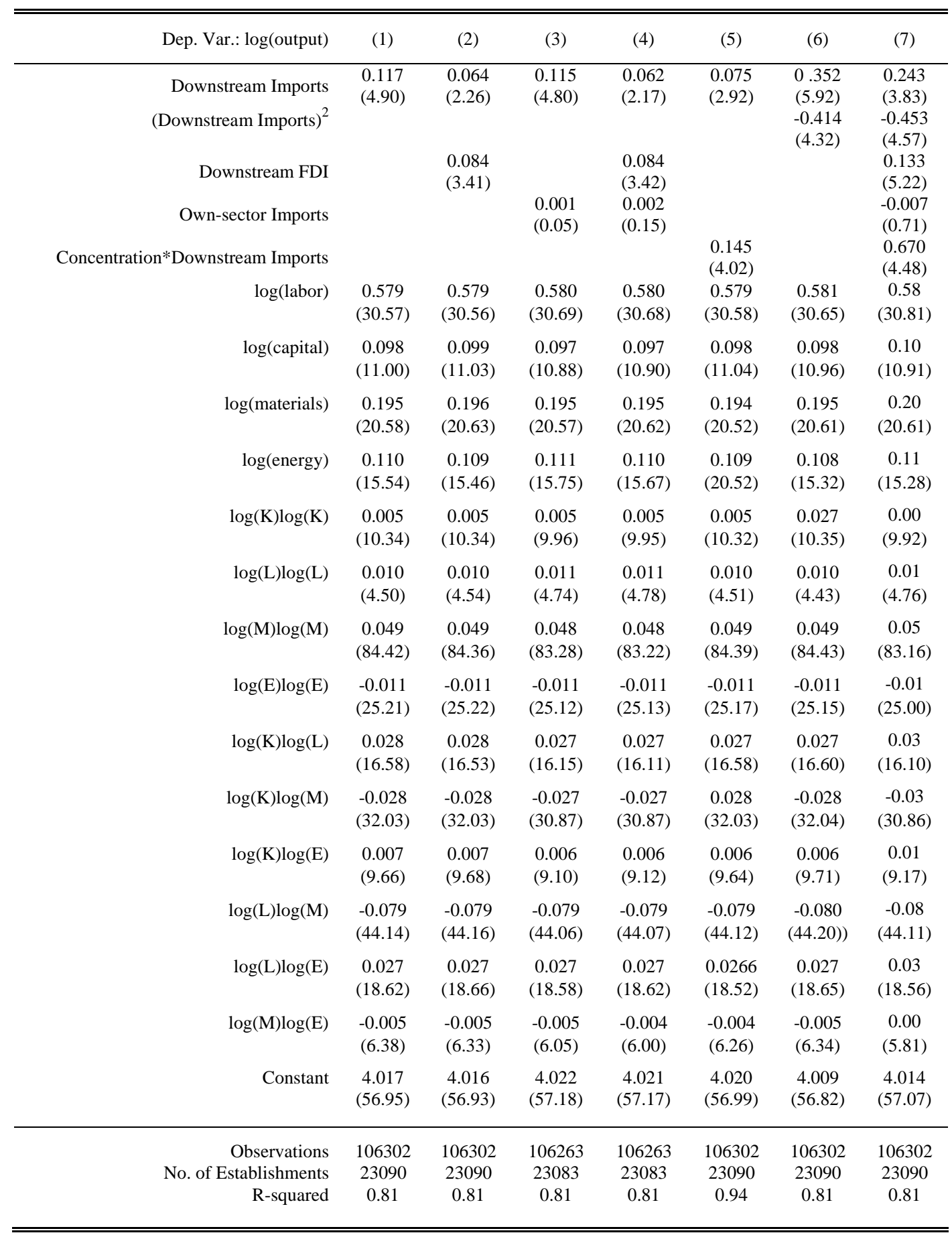

Translog estimation of the effect of downstream imports and own-sector imports on plant productivity.

Factory fixed effects and year indicators are included but not reported. Absolute value of $\mathrm{t}$ statistics in parentheses. 
Table 4: Robustness tests for effects of imports on firm productivity.

\begin{tabular}{|c|c|c|c|c|}
\hline Dep. Var.: $\log$ (output) & $\begin{array}{c}\text { (1) } \\
\text { all factories }\end{array}$ & $\begin{array}{c}\text { (2) } \\
\text { more than } 50 \text { employees }\end{array}$ & $\begin{array}{c}\text { (3) } \\
\text { int. goods sectors }\end{array}$ & $\begin{array}{c}\text { (4) } \\
\text { final goods sectors }\end{array}$ \\
\hline Downstream Imports & $\begin{array}{l}0.064 \\
(2.26)\end{array}$ & $\begin{array}{l}0.110 \\
(2.90)\end{array}$ & $\begin{array}{l}0.090 \\
(3.00)\end{array}$ & $\begin{array}{l}0.037 \\
(1.18)\end{array}$ \\
\hline Downstream FDI & $\begin{array}{l}0.084 \\
(3.41)\end{array}$ & $\begin{array}{l}0.091 \\
(2.79)\end{array}$ & $\begin{array}{l}0.063 \\
(2.42)\end{array}$ & $\begin{array}{l}0.062 \\
(2.29)\end{array}$ \\
\hline $\log$ (labor) & $\begin{array}{c}0.579 \\
(30.56)\end{array}$ & $\begin{array}{c}0.617 \\
(26.25)\end{array}$ & $\begin{array}{c}0.649 \\
(23.91)\end{array}$ & $\begin{array}{c}0.682 \\
(27.37)\end{array}$ \\
\hline $\log$ (capital) & $\begin{array}{c}0.099 \\
(11.03)\end{array}$ & $\begin{array}{l}0.100 \\
(7.67)\end{array}$ & $\begin{array}{l}0.110 \\
(8.18)\end{array}$ & $\begin{array}{l}0.086 \\
(8.04)\end{array}$ \\
\hline $\log$ (materials) & $\begin{array}{c}0.196 \\
(20.63)\end{array}$ & $\begin{array}{c}0.204 \\
(14.47)\end{array}$ & $\begin{array}{c}0.244 \\
(16.75)\end{array}$ & $\begin{array}{l}0.107 \\
(8.84)\end{array}$ \\
\hline $\log ($ energy) & $\begin{array}{c}0.109 \\
(15.46)\end{array}$ & $\begin{array}{l}0.037 \\
(3.52)\end{array}$ & $\begin{array}{c}0.104 \\
(10.41)\end{array}$ & $\begin{array}{l}0.053 \\
(5.83)\end{array}$ \\
\hline $\log (\mathrm{K}) \log (\mathrm{K})$ & $\begin{array}{c}0.005 \\
(10.34)\end{array}$ & $\begin{array}{l}0.005 \\
(7.61)\end{array}$ & $\begin{array}{l}0.006 \\
(8.12)\end{array}$ & $\begin{array}{l}0.005 \\
(9.03)\end{array}$ \\
\hline $\log (L) \log (L)$ & $\begin{array}{l}0.010 \\
(4.54)\end{array}$ & $\begin{array}{l}0.011 \\
(4.13)\end{array}$ & $\begin{array}{l}-0.007 \\
(2.12)\end{array}$ & $\begin{array}{c}0.033 \\
(10.99)\end{array}$ \\
\hline $\log (\mathrm{M}) \log (\mathrm{M})$ & $\begin{array}{c}0.049 \\
(84.36)\end{array}$ & $\begin{array}{c}0.044 \\
(56.17)\end{array}$ & $\begin{array}{c}0.049 \\
(54.76)\end{array}$ & $\begin{array}{c}0.051 \\
(72.04)\end{array}$ \\
\hline $\log (E) \log (E)$ & $\begin{array}{c}-0.011 \\
(25.22)\end{array}$ & $\begin{array}{c}-0.012 \\
(19.80)\end{array}$ & $\begin{array}{l}-0.013 \\
(19.08)\end{array}$ & $\begin{array}{c}-0.009 \\
(16.14)\end{array}$ \\
\hline $\log (K) \log (L)$ & $\begin{array}{c}0.028 \\
(16.53)\end{array}$ & $\begin{array}{l}0.019 \\
(9.49)\end{array}$ & $\begin{array}{c}0.028 \\
(11.55)\end{array}$ & $\begin{array}{c}0.026 \\
(12.31)\end{array}$ \\
\hline $\log (\mathrm{K}) \log (\mathrm{M})$ & $\begin{array}{c}-0.028 \\
(32.03)\end{array}$ & $\begin{array}{l}-0.025 \\
(21.42)\end{array}$ & $\begin{array}{c}-0.031 \\
(22.71)\end{array}$ & $\begin{array}{c}-0.027 \\
(24.95)\end{array}$ \\
\hline $\log (K) \log (E)$ & $\begin{array}{l}0.007 \\
(9.68)\end{array}$ & $\begin{array}{l}0.008 \\
(8.54)\end{array}$ & $\begin{array}{l}0.006 \\
(6.28)\end{array}$ & $\begin{array}{l}0.007 \\
(8.54)\end{array}$ \\
\hline $\log (\mathrm{L}) \log (\mathrm{M})$ & $\begin{array}{c}-0.079 \\
(44.16)\end{array}$ & $\begin{array}{c}-0.074 \\
(32.72)\end{array}$ & $\begin{array}{l}-0.078 \\
(29.88)\end{array}$ & $\begin{array}{c}-0.091 \\
(39.99)\end{array}$ \\
\hline $\log (L) \log (E)$ & $\begin{array}{c}0.027 \\
(18.66)\end{array}$ & $\begin{array}{c}0.026 \\
(14.13)\end{array}$ & $\begin{array}{c}0.031 \\
(15.04)\end{array}$ & $\begin{array}{l}0.015 \\
(7.98)\end{array}$ \\
\hline $\log (M) \log (E)$ & $\begin{array}{l}-0.005 \\
(6.33)\end{array}$ & $\begin{array}{c}0.002 \\
(1.51)\end{array}$ & $\begin{array}{l}-0.005 \\
(4.53)\end{array}$ & $\begin{array}{c}0.002 \\
(1.74)\end{array}$ \\
\hline Constant & $\begin{array}{c}4.016 \\
(56.93)\end{array}$ & $\begin{array}{c}4.225 \\
(39.82)\end{array}$ & $\begin{array}{c}3.411 \\
(31.60)\end{array}$ & $\begin{array}{c}4.641 \\
(52.38)\end{array}$ \\
\hline Observations & 106302 & 57676 & 40642 & 74795 \\
\hline Number of Establishments & 23090 & 10759 & 8493 & 16343 \\
\hline R-squared & 0.81 & 0.83 & 0.83 & 0.81 \\
\hline
\end{tabular}

Translog estimation of downstream imports on firm productivity using (1) all firms, (2) only firms with more than 50

employees, (3) only firms in intermediate goods industries, and (4) only firms in final goods industries.

Factory fixed effects and year indicators are included but not reported. Absolute value of t statistics in parentheses. 


\section{Table 5: Additional robustness tests: Selection, Survival and Aggregation.}

\begin{tabular}{cccc}
\hline \hline & $(1)$ & $(2)$ & (3) \\
Dep. Var.: $\log ($ output) & With control for & Balanced panel of \\
survival & survivors & $\begin{array}{c}\text { Errors clustered in } \\
\text { industry-region-year }\end{array}$ \\
\hline Downstream Imports & 0.101 & 0.088 & 0.144 \\
& $(2.89)$ & $(2.32)$ & $(2.57)$ \\
Downstream FDI & 0.056 & 0.044 & 0.072 \\
Predictor of Survival & $(1.82)$ & $(1.37)$ & $(1.65)$
\end{tabular}

Constant and translog regressors included but not reported.

\begin{tabular}{rccc}
\hline Observations & 25850 & 18228 & 24097 \\
Number of firms & 3828 & 2174 & 4408 \\
R-squared & 0.83 & 0.83 & 0.84 \\
\hline \hline
\end{tabular}

Robustness tests for translog estimation of downstream imports on firm productivity using all firms in intermediate

goods industries (1), those in intermediate sectors that survive the entire panel period (2), and all firms in intermediate

goods industries that have 50 workers in one or more years (3).

Factory fixed effects and year indicators included but not reported. Absolute value of $\mathrm{t}$ statistics in parentheses.

Table 6: Effect of imports on plant productivity for selected ISIC sectors

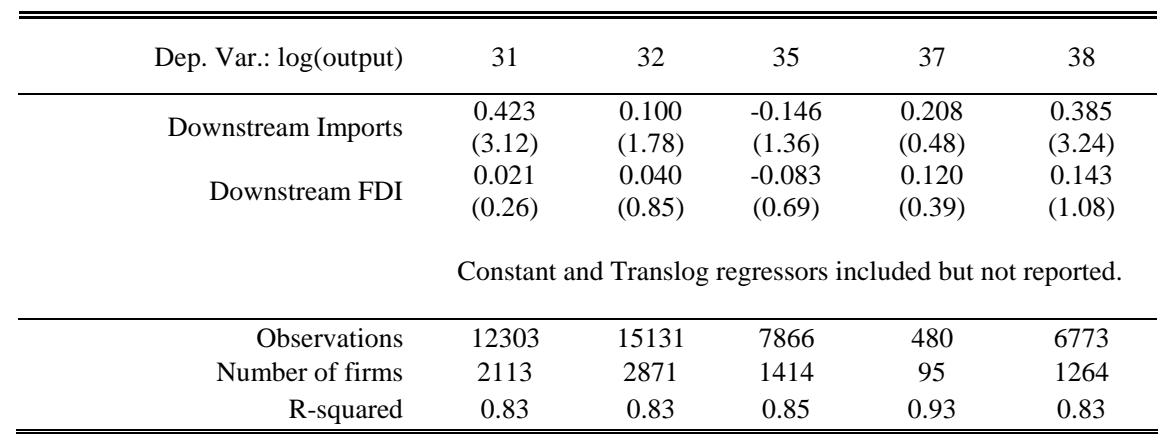

Sectors included: 31 - food and beverage, 32 - textiles, 35 - chemicals, 37 - metals; 38 - machinery. Factory

fixed effects and year indicators are included but not reported. Absolute value of $t$ statistics in parentheses. 


\section{APPENDIX}

\section{Construction of Price Deflators}

Output, materials, and capital are deflated to express values in real terms. The deflators are based on Indeks Harga Perdangangan Besar (IHPB), wholesale price indexes (WPI), published monthly in BPS's Buletin Statistik Bulanan Indikator Ekonomi, the Monthly Statistical Bulletin of Economic Indicators. To calculate WPI, BPS field officers interview representative firms in all provinces to collect prices for five categories of commodities: agriculture, manufacturing, mining and quarrying, imports, and exports. In total, prices are available for 327 commodities, 192 of which are manufactured commodities.

\section{Output, Materials, and Energy Deflators}

Nominal rupiah output and materials values are deflated using the WPI for the nearest corresponding manufactured commodity. BPS officials provided an unpublished concordance table mapping the 192 WPI commodity codes to the 329 5-digit ISIC product codes. Energy is deflated using Indonesian petroleum prices.

\section{Capital Deflators}

Fixed assets are deflated using the WPI for manufactured construction materials and imported machinery. Specifically, the capital deflator combines the WPI for construction materials, imported electrical and non-electrical machinery, and imported transportation equipment. We weighted these price indexes by the average reported value shares of building and land, machinery, and vehicle fixed assets in the SI survey to obtain an annual capital deflator. 


\section{Concordance of Rev. 1 and Rev. 2 ISIC Codes}

The industrial survey reports revision 1 ISIC codes prior to 1990 and revision 2 codes thereafter. Attempts to create a concordance table at the 5-digit level from rev. 1 to rev. 2 codes yielded disappointing results. Comparing code changes for the same establishment before and after 1990 showed that the concordance table predictions were incorrect as often as half the time. Rather than accept the noise introduced by these mistakes, the analysis attempts to assign each establishment's actual rev. 2 code to its observations in 1988-1989. Specifically, for each establishment that appears in either 1988 or 1989, the analysis looks for the earliest appearance of the same establishment in 1990 and later years. In most cases, the rev. 2 code from the 1990 observation could be used. If the establishment did not appear in 1990, the rev. 2 code from 1991 or 1992 was used. If the establishment did not appear between 1990 and 1992, it was dropped. This process greatly improved the precision of ISIC code assignments at the cost of dropping about 5 percent of the 1988-1989 sample. Since the dropped establishments appear in only one or two years anyway, the 5 percent loss has little effect on the results.

\section{Concordance of Input-Output Table Code and ISIC Codes}

The IO table was published in 1990 and 1995 with four variants: domestic transactions at producer prices, domestic transactions at purchaser prices, domestic and export transactions at producer prices, and domestic and export transactions at purchaser prices. The analysis here considers domestic transactions at producer prices. Both the 1990 and 1995 IO tables classified industrial production into 89 categories. To merge the IO table with the SI, first the 1995 IO table codes were concorded with the 1990 IO table codes. Next, the 1990 IO table codes were concorded with the 329 5-digit ISIC codes reported in the SI. The 1990 IO codes were used to define industries in the analysis. 